УДК 332.12

$10.17213 / 2075-2067-2020-6-172-184$

\title{
ИССЛЕДОВАНИЕ СТРУКТУРЫ ЭКОНОМИКИ РЕСПУБЛИКИ БЕЛАРУСЬ И МОНИТОРИНГ ТЕНДЕНЦИЙ ЕЕ РАЗВИТИЯ В СРАВНЕНИИ С ОБЩЕМИРОВЫМИ ЭКОНОМИЧЕСКИМИ ПОКАЗАТЕЛЯМИ
}

\author{
(C) 2020 г. М. В. Камына
}

\section{Научно-исследовательский экономический институт Министерства экономики Республики Беларусь, г. Минск, Республика Беларусь}

Целью исследования является характеристика некоторых видов структур экономики Республики Беларусь: показатели, характеризующие структуру экономики, а также факторы, влияющие на структуру экономики. Кроме того, сравниваются экономические показатели Республики Беларусь с общемировыми экономическими показателями.

Методологическую базу исследования представляют структурный анализ, элементы эконометрического моделирования и сравнительного анализа. Применение этих методов и подходов позволяет изучить показатели объема производства продукции обрабатывающей промышленности в иелом, на душу населения и по подсекииям обрабатывающей промышленности, а также показатели технологичности, экспорта и экспорта в промышленности, кроме того, дает возможность составить рейтинг рассматриваемых стран по показателям производства продукции обрабатывающей промышленности, а также производства продукиии обрабатывающей промьлиленности на душу населения.

Результаты исследования. Одним из важных результатов является утверждение, что Беларусь выдержсивает сравнение с другими странами по экономическим показателям, в том числе и со странами-лидерами. Обрабатывающая промышленность представлена многими подсекциями, по некоторым подсекциям Беларусь имеет конкурентное преимущество на мировой арене.

Наибольшую долю в структуре обрабатывающей промышленности в Республике Беларусь занимает подсекиия «Еда и напитки». Подобная ситуация наблюдается и в других странах. Однако, в некоторых развитых странах в структуре обрабатывающей промыиленности превалируют подсекциии, выпускающие продукцию с более высокой ВДС, такие как «Автомобили, прицепы и полуприцепь», «Машины и оборудование», «Химикаты и химические продукты», и являющиеся также ориентированными на экспорт.

Показатели технологичности, экспорта, экспорта в промышленности Беларуси демонстрируют средние значения среди рассмотренных стран. Наименьшие значения наблюдались в индексах таких стран, как Россия, Казахстан, Латвия, Австралия, наибольшие значения в индексах Германии, Чехии и Франции.

Перспектива исследования. Данная статья подготовлена в рамках комплексного исследования, посвященного совершенствованию структуры экономики регионов областного и районного уровней Республики Беларусь.

Ключевые слова: структура экономики; структура обрабатывающей промышленности; общемировые экономические показатели. 


\title{
STUDY OF THE STRUCTURE OF THE BELARUSIAN ECONOMY AND MONITORING OF ITS DEVELOPMENT TRENDS IN COMPARISON WITH GLOBAL ECONOMIC INDICATORS
}

\author{
(C) 2020 M. V. Kamyna
Research Institute of Economics of the Ministry of Economy of the Republic of Belarus, Minsk, Republic of Belarus

The purpose of the study is to characterize some types of economic structures of the Republic of Belarus: indicators that characterize the structure of the economy, as well as factors that affect the structure of the economy. In addition, the economic indicators of the Republic of Belarus are compared with global economic indicators.

The methodological basis of the research is structural analysis, elements of econometric modeling and comparative analysis. The application of these methods and approaches allows to study the production of manufactures as a whole, per capita and subsections of the manufacturing industry, as well as the manufacturability, import and export in the industry. In addition, to make a rating of the countries under consideration in terms of manufacturing production, as well as manufacturing production per capita.

Research result. One of the important results is the statement that Belarus stands up to comparison with other countries in terms of economic indicators, including with the leading countries. The manufacturing industry is represented by many subsections, and in some subsections Belarus has a competitive advantage on the world stage.

The largest share in the structure of the manufacturing industry in the Republic of Belarus is occupied by the "Food and beverages» subsection. A similar situation is observed in other countries. However, in some developed countries, the structure of the manufacturing industry is dominated by subsections that produce products with higher GVA, such as «Cars, trailers and semi-trailers», "Machinery and equipment», "Chemicals and chemical products», and are also export-oriented.

Indicators of manufacturability, exports, and exports in the industry of Belarus show average values among the countries considered. The lowest values were observed in the indices of such countries as Russia, Kazakhstan, Latvia, and Australia, the highest values were in Germany, the Czech Republic, and France.

Research perspective. This article was prepared as part of a comprehensive study on improving the structure of the economy of regions at the regional and district levels of the Republic of Belarus.

Key words: the structure of the economy; the structure of manufacturing; general economic indicators.

Введение. В настоящее время наибольшей конкурентоспособностью обладают страны, которые успешно провели структурную перестройку национальных экономических систем и осуществили переход к постиндустриальному этапу развития. Для обеспечения сбалансированности структурных преобразований, направленных на устойчи- вое социально-экономическое развитие государства, необходимо проведение тщательного исследования структуры национальной экономики.

В целом проблемам экономической структуры посвящено достаточно большое количество работ ученых из советских и постсоветских государств и экономистов из даль- 
него зарубежья. В их числе такие известные экономисты, как Л.И. Абалкин, С. В. Белова, Л.М. Гатовский, В.А. Медведев, Г.М. Сорокин, П.Н. Федосеев. Среди белорусских ученых следует назвать А.В. Богдановича, Н. Г. Берченко, В.Н.Кивеля, В. С. Фатеева.

Тем не менее, специальных исследований, посвященных проблемам изучения различных видов структур экономики региона и их взаимосвязи, недостаточно. Теоретические вопросы, касающиеся механизмов совершенствования структуры региональной экономики, слабо проработаны и не выделены в практикоориентированные меры.

\section{Исследование некоторых видов струк-} тур экономики Республики Беларусь. Структуру экономики можно рассматривать в отраслевом, территориальном и социальном разрезах. Одновременно с ними выделяют следующие типы структур экономики: территориальная структура, отраслевая структура экономики, структура факторов воспроизводства, стоимостная структура, структура в разрезе крупных ее секторов, структура производства и потребления, структура внутренних и внешних связей, структура инвестиций, социальная структура экономики, технологическая структура и другие. Каждая из составляющих структуры экономики позволяет более полно изучить различные стороны и свойства мультиструктуры экономики. Под мультиструктурой понимается структура экономики, объединяющая в себе различные виды структур экономики и их взаимосвязи [1].

В таблице 1 приведены некоторые виды структур экономики: территориальная, отраслевая, секторальная, технологическая, региональная, инвестиционная, инновационная структуры экономики, структура форм собственности, представлены показатели, характеризующие их, а также факторы, влияющие на них.

Сравнение экономических показателей Республики Беларусь с общемировыми экономическими показателями. Для того чтобы правильно оценивать уровень экономического развития в Беларуси, необходимо сопоставлять важнейшие показатели в этой области с соответствующими показа- телями в других странах. Для того чтобы исследовать и оценивать различные виды структур экономики Республики Беларусь, необходимо сопоставлять их со схожими структурами других стран. Учитывая, что настоящее исследование проводится в категориях структуры экономики, рассматриваются различные виды структур экономики и показатели, характеризующие их, целесообразно сравнивать Беларусь с другими странами по тем же показателям. Это достаточно сложно, учитывая, что даже классификация видов деятельности в Беларуси отличается от зарубежных классификаций. Кроме того, иногда бывает сложно найти в открытом доступе показатели, характеризующие экономическое развитие зарубежных стран. Поэтому для сравнения показателей воспользовались статистической базой данных Организации промышленного развития ОOH (UNIDO), а точнее, показателями и данными со статистического портала этой организации [3].

В таблице 2 приведены показатели в оригинальном названии и в переводе. Кроме сравнения показателей и определения места нашей страны в рейтинге по тем или иным показателям, в результате исследования определялись тенденции стран относительно объема промышленного производства, производства в обрабатывающей промышленности и некоторых других показателей.

Рассмотренные показатели близки к тем, которые были взяты для характеристики некоторых видов структуры экономики Республики Беларусь (таблица 1). Предполагается, что продукция промышленности, и в частности, обрабатывающей промышленности, характеризует отраслевую структуру экономики. Доля добавленной стоимости в среднеи высокотехнологичном производстве в общей добавленной стоимости производства и доля экспорта средне- и высокотехнологичных товаров в общем объеме экспорта характеризуют технологическую, инновационную, инвестиционную структуры. В таблице 3 приведено авторское предположение по поводу отнесения этих и других оцениваемых показателей.

Для сравнения экспертным образом было выбрано 15 стран, включая Беларусь: Австралия, Беларусь, Китай, Чехия, Эстония, 
Характеристика некоторых видов структур экономики РБ [3-6]

\begin{tabular}{|c|c|c|}
\hline $\begin{array}{l}\text { Структура } \\
\text { экономики }\end{array}$ & $\begin{array}{c}\text { Показатели, характеризующие } \\
\text { структуру экономики }\end{array}$ & $\begin{array}{c}\text { Факторы, влияющие } \\
\text { на структуру экономики }\end{array}$ \\
\hline Отраслевая & $\begin{array}{l}\text { Численность занятых по отраслям; объем } \\
\text { производства продукции по отраслям; объ- } \\
\text { ем отгруженной инновационной продукции } \\
\text { по отраслям; стоимость фондов. }\end{array}$ & $\begin{array}{l}\text { Темпы экономического раз- } \\
\text { вития, концентрация произ- } \\
\text { водства, трудового потенци- } \\
\text { ала; сырьевые базы; развитие } \\
\text { интеграционных процессов. }\end{array}$ \\
\hline Секторальная & $\begin{array}{l}\text { Занятость в секторах экономики, доля сек- } \\
\text { торов экономики в ВВП. }\end{array}$ & $\begin{array}{l}\text { Характер и темпы научно- } \\
\text { технического прогресса. }\end{array}$ \\
\hline Территориальная & $\begin{array}{l}\text { Объем производства продукции, объем про- } \\
\text { мышленной продукции на душу населения, } \\
\text { рассчитываемый по соответствующим АТЕ. }\end{array}$ & $\begin{array}{l}\text { Концентрация производс- } \\
\text { тва, трудового потенциала; } \\
\text { природные ресурсы. }\end{array}$ \\
\hline Региональная & $\begin{array}{l}\text { Удельных вес регионов в основных соци- } \\
\text { ально-экономических показателях Респуб- } \\
\text { лики Беларусь. Для региональной струк- } \\
\text { туры имеет значение деление регионов по } \\
\text { уровню экономического развития, выявле- } \\
\text { ние и анализ диспропорций в территори- } \\
\text { альной структуре производства. }\end{array}$ & $\begin{array}{l}\text { Распределение платежеспо- } \\
\text { собного спроса населения по } \\
\text { территории страны; распре- } \\
\text { деление рабочей силы и ее } \\
\text { занятости, миграция населе- } \\
\text { ния; размещение источников } \\
\text { сырья, топлива, энергии. }\end{array}$ \\
\hline Инновационная & $\begin{array}{l}\text { Внутренние затраты на научные исследо- } \\
\text { вания и разработки, в \% к ВВП; удельный } \\
\text { вес инновационно-активных организаций, } \\
\text { осуществлявших затраты на технологичес- } \\
\text { кие инновации; удельный вес отгруженной } \\
\text { инновационной продукции в общем объеме } \\
\text { отгруженной продукции промышленности; } \\
\text { число организаций промышленности по ви- } \\
\text { дам инновационной деятельности. }\end{array}$ & $\begin{array}{l}\text { Характер и темпы научно- } \\
\text { технического прогресса. }\end{array}$ \\
\hline Инвестиционная & $\begin{array}{l}\text { Структура инвестиционных ресурсов по сек- } \\
\text { торам экономики; удельный вес инвестиций в } \\
\text { основной капитал в ВВП; удельный вес реги- } \\
\text { онов в общем объеме инвестиций в основной } \\
\text { капитал по стране; инвестиции в основной } \\
\text { капитал по формам собственности. }\end{array}$ & $\begin{array}{l}\text { Характер и темпы научно- } \\
\text { технического прогресса. }\end{array}$ \\
\hline Технологическая & $\begin{array}{l}\text { Структура обрабатывающей промышлен- } \\
\text { ности страны; структура производства про- } \\
\text { дукции; доля добавленной стоимости в сред- } \\
\text { не- и высокотехнологичном производстве в } \\
\text { общей добавленной стоимости производс- } \\
\text { тва; доля экспорта средне- и высокотехноло- } \\
\text { гичных товаров в общем объеме экспорта. }\end{array}$ & $\begin{array}{l}\text { Технологическая структура } \\
\text { зависит от научно-техничес- } \\
\text { кого потенциала, возмож- } \\
\text { ностей финансового стиму- } \\
\text { лирования. }\end{array}$ \\
\hline $\begin{array}{l}\text { Структура форм } \\
\text { собственности }\end{array}$ & $\begin{array}{l}\text { Структура форм собственности характеризу- } \\
\text { ется удельным весом различных видов форм } \\
\text { собственности. Количество организаций по } \\
\text { формам собственности; численность занято- } \\
\text { го населения по формам собственности. }\end{array}$ & $\begin{array}{l}\text { Структура форм собствен- } \\
\text { ности определяется наличи- } \\
\text { ем развитой предпринима- } \\
\text { тельской структуры в регио- } \\
\text { не; возможностями привле- } \\
\text { чения инвестиций в регион. }\end{array}$ \\
\hline
\end{tabular}


Франция, Германия, Италия, Казахстан, Латвия, Литва, Польша, Россия, Испания, США. Выбор стран осуществлялся на основании предположения о положении Республики Беларусь на мировой арене по экономическим параметрам. Были выбраны страны - лидеры по экономическим показателям, страны соседи Беларуси, а также страны со сходной структурой экономики.

Учитывая, что население в рассматриваемых странах очень неравномерно распределено, чтобы сгладить различия и для лучшей сопоставимости экономических показателей, в дальнейшем большинство показателей рассматривается на душу населения.

В данной статье подробно рассматриваются показатели объема производства продукции обрабатывающей промышленности в целом, на душу населения и по подсекциям обрабатывающей промышленности, а также приводятся показатели технологичности, экспорта и экспорта в промышленности.

В таблице 4 приведена структура обрабатывающей промышленности в представле-

нии на статистическом портале Организации промышленного развития ОOH (UNIDO).

Исходя из значений продукции обрабатывающей промышленности на душу населения в 2010 и 2017 гг., лидером среди рассмотренных стран является Германия 25,1 тыс. долларов на человека в 2017 г. Далее идут Чехия - 17,9 тыс. долларов на человека и США - 17,1 тыс. долларов на человека. В Беларуси показатель составил 4,4 тыс. долларов на человека и снизился в 2017 г. по сравнению с 2010 г. на 17\%. Ниже, чем у Беларуси, среди рассмотренных стран в 2017 г. показатели у следующих стран: Латвия - 4,2 тыс. долларов на человека и Казахстан - 1,9 тыс. долларов на человека. Снижение данного показателя за период 2010-2017 гг. кроме Беларуси произошло в следующих странах: Австралия (27\%), Германия (2\%), Испания (2,5\%), Италия (10\%), Казахстан (5\%).

Представляет интерес структура обрабатывающей промышленности других стран, ее сравнение со структурой обрабатывающей

Таблица 2

\section{Сопоставление показателей в рамках исследования структур экономики [3]}

\begin{tabular}{|l|l|}
\hline \multicolumn{1}{|c|}{ Показатель в оригинале } & \multicolumn{1}{|c|}{ Перевод } \\
\hline Manufacturing Value Added per capita & $\begin{array}{l}\text { Добавленная стоимость производства на душу на- } \\
\text { селения }\end{array}$ \\
\hline Manufactured Exports per capita & Производимый экспорт на душу населения \\
\hline $\begin{array}{l}\text { Medium- and High-tech Manufacturing } \\
\text { Value Added share in total manufacturing } \\
\text { value added }\end{array}$ & $\begin{array}{l}\text { Доля добавленной стоимости средне- и высоко- } \\
\text { технологичного производства в общей добавлен- } \\
\text { ной стоимости производства }\end{array}$ \\
\hline $\begin{array}{l}\text { Medium- and High-tech manufactured } \\
\text { Exports share in total manufactured exports }\end{array}$ & $\begin{array}{l}\text { Доля экспорта средне- и высокотехнологичных то- } \\
\text { варов в общем объеме экспорта }\end{array}$ \\
\hline Manufactured Exports per capita index & Индекс экспорта производства на душу населения \\
\hline $\begin{array}{l}\text { Share of manufactured exports in total } \\
\text { exports index }\end{array}$ & $\begin{array}{l}\text { Доля экспорта промышленной продукции в об- } \\
\text { щем объеме экспорта }\end{array}$ \\
\hline $\begin{array}{l}\text { Share of Medium and High-Tech Activities } \\
\text { in Manufacturing Export Index }\end{array}$ & $\begin{array}{l}\text { Доля средне- и высокотехнологичной деятельности в } \\
\text { индексе экспорта обрабатывающей промышленности }\end{array}$ \\
\hline Industrial export quality index & Индекс качества промышленного экспорта \\
\hline Population & Население \\
\hline GDP & ВВП \\
\hline MVA & ВДС \\
\hline Manufactoring (D) & $\begin{array}{l}\text { Объем производства продукции обрабатывающей } \\
\text { промышленности }\end{array}$ \\
\hline
\end{tabular}


промышленности нашей страны. В 2017 г. в структуре обрабатывающей промышленности многих из рассмотренных стран превалирует подсекция «Еда и напитки»: Австралия (28,3\%), Беларусь (29,3\%), Франция $(20,8 \%)$, Литва (27\%), Испания $(23,5 \%)$, США (16,5\%).

В Беларуси наибольший вес в структуре обрабатывающей промышленности занимают 3 подсекции: «Еда и напитки» $(29,3 \%)$, «Кокс, очищенные нефтепродукты, ядерное топливо» $(14,8 \%)$, «Химикаты и химические продукты» (10,8\%) (рисунок 1$)$.

Далее рассмотрена структура обрабатывающей промышленности стран - лидеров по показателям производства продукции обрабатывающей промышленности, а также производства продукции обрабатывающей промышленности на душу населения.
Китай в 2017 г. из всех рассмотренных стран лидировал по производству продукции обрабатывающей промышленности. В структуру обрабатывающей промышленности Китая наибольший вклад вносят «Химикаты и химические продукты» $(12,1 \%)$, «Основные металлы» $(11,6 \%)$, «Еда и напитки» $(10,4 \%)$. Надо заметить, что остальные подсекции достаточно равномерно развиты и вносят существенный вклад в структуру обрабатывающей промышленности.

США находились на втором месте по производству продукции обрабатывающей промышленности и на третьем по производству продукции обрабатывающей промышленности на душу населения. В США наибольший вес в структуре обрабатывающей промышленности занимают 3 подсекции: «Еда и на-

Таблица 3

Сопоставление показателей в рамках исследования структур экономики [3-6]

\begin{tabular}{|l|l|}
\hline \multicolumn{1}{|c|}{ Показатель } & \multicolumn{1}{|c|}{\begin{tabular}{c}
\multicolumn{1}{c|}{ Структура, } \\
которую показатель характеризует
\end{tabular}} \\
\hline Население & $\begin{array}{l}\text { Вспомогательный показатель для ха- } \\
\text { рактеристики различных структур }\end{array}$ \\
\hline ВВП & $\begin{array}{l}\text { Вспомогательный показатель для ха- } \\
\text { рактеристики различных структур }\end{array}$ \\
\hline ВдС & $\begin{array}{l}\text { Вспомогательный показатель для ха- } \\
\text { рактеристики различных структур }\end{array}$ \\
\hline $\begin{array}{l}\text { Продукция обрабатывающей промышленности } \\
\text { процентном отношении к ВВП }\end{array}$ & Отраслевая \\
\hline Продукция обрабатывающей промышленности & Отраслевая \\
\hline Добавленная стоимостьпроизводствана душу населения & Отраслевая \\
\hline Производимый экспорт на душу населения & Отраслевая \\
\hline $\begin{array}{l}\text { Доля добавленной стоимости в средне- и высокотех- } \\
\text { нологичном производстве в общей добавленной сто- } \\
\text { имости производства }\end{array}$ & $\begin{array}{l}\text { Технологическая, инновационная, } \\
\text { инвесиционная }\end{array}$ \\
\hline $\begin{array}{l}\text { Доля экспорта средне- и высокотехнологичных това- } \\
\text { ров в общем объеме экспорта }\end{array}$ & $\begin{array}{l}\text { Технологическая, инновационная, } \\
\text { инвестиционная }\end{array}$ \\
\hline Индекс производства на душу населения & Отраслевая \\
\hline $\begin{array}{l}\text { Доля экспорта промышленной продукции в общем } \\
\text { объеме экспорта }\end{array}$ & Отраслевая \\
\hline $\begin{array}{l}\text { Доля средней и высокотехнологичной деятельности в } \\
\text { индексе экспорта обрабатывающей промышленности }\end{array}$ & Технологическая, инновационная \\
\hline $\begin{array}{l}\text { Индекс качества промышленного экспорта } \\
\text { Технологическая }\end{array}$ \\
\hline
\end{tabular}


питки» (16,5\%), «Химикаты и химические продукты» $(13,6 \%)$, «Автомобили, прицепы и полуприцепы» $(12,1 \%)$. Другие подсекции также равномерно развиты и вносят существенный вклад в структуру обрабатывающей промышленности США.

Германия находилась на третьем месте по производству продукции обрабатывающей промышленности и на первом по производству продукции обрабатывающей промышленности на душу населения. Здесь наибольший вес в структуре обрабатывающей промышленности занимают 3 подсекции: «Автомобили, прицепы и полуприцепы»
$(19,2 \%)$, «Машины и оборудование» $(16,0 \%)$, «Еда и напитки» $(9,7 \%)$.

Чехия находилась на втором месте по производству продукции обрабатывающей промышленности на душу населения. Наибольший вес в структуре обрабатывающей промышленности занимают 3 подсекции: «Автомобили, прицепы и полуприцепы» $(29,1$ \%), «Машины и оборудование» $(10,3 \%)$, «Изготовленные металлические изделия» $(8,7 \%)$. Секция «Еда и напитки» $(7,5 \%)$ находится на пятом месте по вкладу в общий объем обрабатывающей промышленности.

\section{Виды деятельности обрабатывающей промышленности (секция D) [3]}

\begin{tabular}{|l|l|}
\hline \multicolumn{1}{|c|}{ Показатель в оригинале } & \multicolumn{1}{|c|}{ Перевод } \\
\hline Food and beverages & Еда и напитки \\
\hline Tobacco products & Табак \\
\hline Textiles & Текстиль \\
\hline Wearing apparel, fur & Одежда, мех \\
\hline Leather, leather products and footwear & Кожа, изделия из кожи, обувь \\
\hline Wood products (excl. furniture) & Продукты из дерева \\
\hline Paper and paper products & Бумага \\
\hline Printing and publishing & Полиграфия и издательство \\
\hline Coke, refined petroleum products, nuclear fuel & $\begin{array}{l}\text { Кокс, очищенные нефтепродукты, ядерное } \\
\text { топливо }\end{array}$ \\
\hline Chemicals and chemical products & Химикаты и химические продукты \\
\hline Rubber and plastics products & Резиновые и пластмассовые изделия \\
\hline Non-metallic mineral products & Неметаллические минеральные продукты \\
\hline Basic metals & Основные металлы \\
\hline Fabricated metal products & Изготовленные металлические изделия \\
\hline Machinery and equipment n.e.c & Машины и оборудование \\
\hline Office, accounting and computing machinery & $\begin{array}{l}\text { Офисная, бухгалтерская и вычислительная } \\
\text { техника }\end{array}$ \\
\hline Electrical machinery and apparatus & Электрические машины и аппараты \\
\hline Radio, television and communication equipment & Радио, телевидение и оборудование связи \\
\hline Medical, precision and optical instruments & $\begin{array}{l}\text { Медицинские, точные и оптические } \\
\text { инструменты }\end{array}$ \\
\hline Motor vehicles, trailers, semi-trailers & Автомобили, прицепы, полуприцепы \\
\hline Other transport equipment & Другое транспортное оборудование \\
\hline Furniture; manufacturing (o) n.e.c. & Мебель; производство \\
\hline Recycling & Переработка отходов \\
\hline
\end{tabular}


Результаты ранжирования рассматриваемых стран по показателям производства продукции обрабатывающей промышленности, а также производства продукции обрабатывающей промышленности на душу населения приведены в таблице 5.

Необходимо отметить, что в рейтинге Беларусь ни разу не попала на последнее 15-е место ни в первом, ни во втором случае. $\mathrm{B}$ рейтинге по объему производства продукции обрабатывающей промышленности Беларусь попала в десятку стран по 4 подсекциям, по объему производства продукции обрабатывающей промышленности на душу населения Беларусь попала в десятку стран по 3 подсекциям.

По объему продукции обрабатывающей промышленности Беларусь опережала следующие страны: Эстонию - в 73,7\% случаев, Латвию - в 89,5\% случаев, Литву в 78,9\% случаев, Казахстан - в 94,7\% случаев, Чехию - в 15,8 \% случаев, Францию в $10,5 \%$ случаев, Россию - в $5,3 \%$ случаев. По объему продукции обрабатывающей промышленности на душу населения Беларусь опережала следующие страны: Эстонию в $21,1 \%$ случаев, Латвию - в $52,6 \%$ случаев, Литву — в 31,6\% случаев, Казахстан в $94,7 \%$ случаев, Чехию - в $15,8 \%$ случаев, Францию - в 10,5\% случаев, Россию в $5,3 \%$ случаев, Китай - в $10,5 \%$ случаев, США - в 5,3\% случаев, Германию - в 5,3\% случаев, Польшу - в 10,5\% случаев, Австралию - в 10,5\% случаев, Италию — в 5,3\% случаев.

Учитывая, что одной из задач национальной стратегии устойчивого социально-экономического развития Республики Беларусь на период до 2030 г. является «поддерживать разработки, исследования и инновации в сфере отечественных технологий в развивающихся странах, в том числе путем создания политического климата, благоприятствующего диверсификации промышленности и увеличению добавленной стоимости (ДС) в сырьевых отраслях», индикатором считается показатель «Доля ДС продукции среднетехнологичных и высокотехнологичных отраслей в общем объеме ДС» [1]. Этот и другие показатели, приведенные в таблицах 6-8, характеризуют технологическую, инновационную, инвестиционную структуры экономики. Для удобства представления и по смыслу показатели были сгруппированы следующим образом: показатели технологичности (доля ДС средне- и высокотехнологичного производства в общей ДС производства, доля экспорта средне- и высокотехнологичных товаров в общем объеме экспорта), экспорта (индекс экспорта производства на душу населения, доля экспорта промышленной продукции в общем объеме экспорта), экспорта в промышленности (доля средне- и высокотехно-

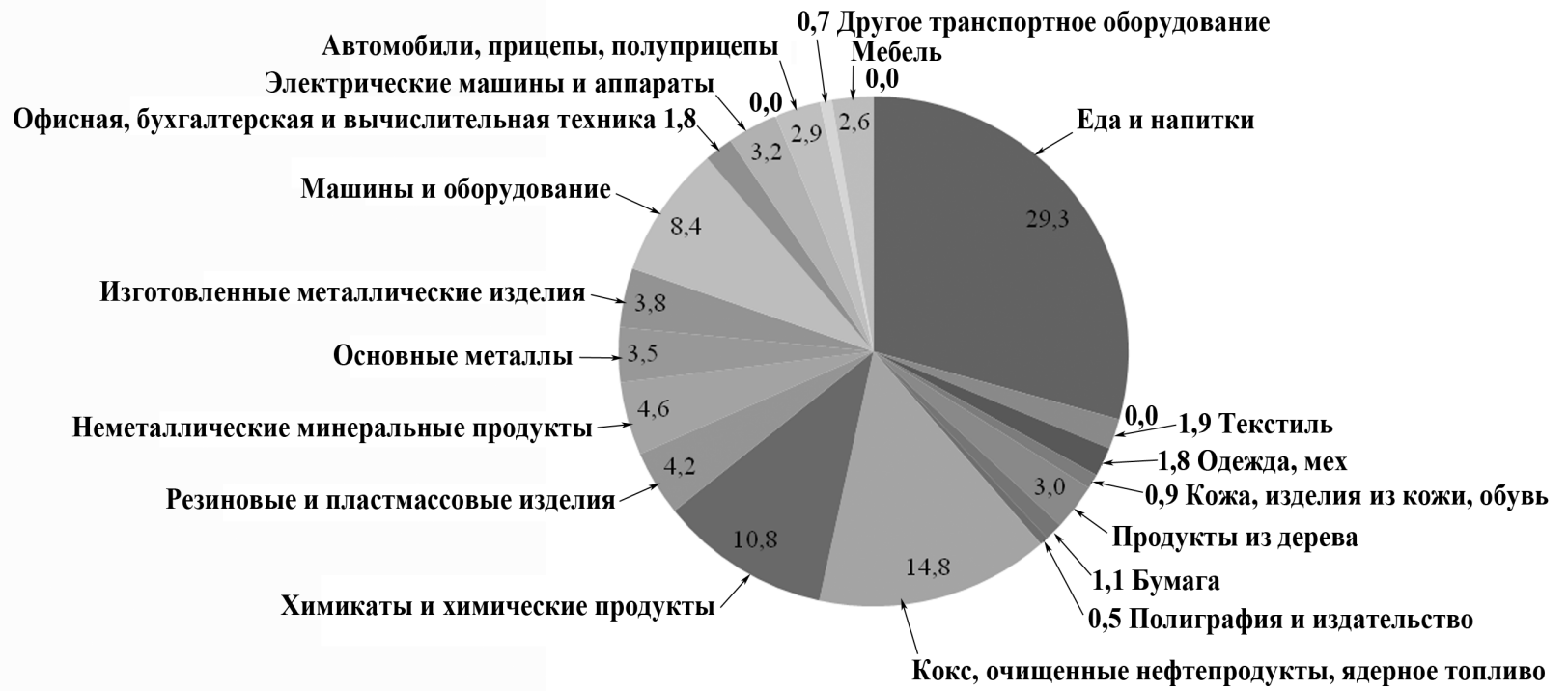

Рис. 1. Структура обрабатывающей промышленности, объем производства на душу населения в РБ, 2017 г. 
логичной деятельности в индексе экспорта обрабатывающей промышленности, индекс качества промышленного экспорта).

Исходя из индексов доли ДС среднеи высокотехнологичного производства в общей ДС производства, можно сказать, что наибольшие значения среди представленных стран у Германии, Чехии и Франции, наименьшие значения - у России, Латвии, Казахстана. В Беларуси показатель составил 0,4 п., что является средним значением среди значений рассмотренных стран.
Наибольшие значения доли экспорта средне- и высокотехнологичных товаров в общем объеме экспорта среди представленных стран наблюдаются также у Германии, Чехии и Франции, наименьшие значения - у России, Латвии, Австралии. В Беларуси показатель составил приблизительно 0,4 п., что также является средним значением среди значений рассмотренных стран (таблица 6).

Исходя из индексов экспорта производства на душу населения, отметим, что наиболь-

\section{Позиция Беларуси в рейтинге стран по объему производства продукции обрабатывающей промышленности, 2017 г. (составлено автором на основании стат. базы данных ООН)}

Таблица 5

\begin{tabular}{|c|c|c|}
\hline \multirow[b]{2}{*}{ Подсекция } & \multicolumn{2}{|c|}{ Позиция Беларуси (1-15) } \\
\hline & $\begin{array}{c}\text { Продукция } \\
\text { секции }\end{array}$ & $\begin{array}{c}\text { Продукции } \\
\text { секции на душу } \\
\text { населения }\end{array}$ \\
\hline Еда и напитки & 11 & 12 \\
\hline Табак & - & - \\
\hline Текстиль & 10 & 12 \\
\hline Одежда, мех & 11 & 10 \\
\hline Кожа, изделия из кожи, обувь & 10 & 6 \\
\hline Продукты из дерева & 14 & 14 \\
\hline Бумага & 12 & 14 \\
\hline Полиграфия и издательство & 14 & 14 \\
\hline Кокс, очищенные нефтепродукты, ядерное топливо & 10 & 5 \\
\hline Химикаты и химические продукты & 11 & 12 \\
\hline Резиновые и пластмассовые изделия & 11 & 13 \\
\hline Неметаллические минеральные продукты & 11 & 14 \\
\hline Основные металлы & 12 & 12 \\
\hline Изготовленные металлические изделия & 11 & 14 \\
\hline Машины и оборудование & 11 & 12 \\
\hline Офисная, бухгалтерская и вычислительная техника & 12 & 13 \\
\hline Электрические машины и аппараты & 11 & 12 \\
\hline Радио, телевидение и оборудование связи & - & - \\
\hline Медицинские, точные и оптические инструменты & - & - \\
\hline Автомобили, прицепы, полуприцепы & 11 & 12 \\
\hline Другое транспортное оборудование & 10 & 13 \\
\hline Мебель; производство & 12 & 14 \\
\hline Переработка отходов & - & - \\
\hline
\end{tabular}


шие значения среди представленных стран у Германии, Чехии и Эстонии, наименьшие значения - у России, Китая, Казахстана. В Беларуси показатель составил 0,07-0,08 п., что является значением ниже среднего среди значений рассмотренных стран (таблица 7).

Наибольшие значения доли экспорта промышленной продукции в общем объеме экспорта среди представленных стран наблюдаются у Китая, Чехии и Италии, наименьшие значения - у России, Казахстана, Австралии. В Беларуси показатель составил примерно 0,9 п., что является значением выше среднего среди значений рассмотренных стран.

Исходя из доли средне- и высокотехнологичной деятельности в индексе экспорта обрабатывающей промышленности, можно сказать, что наибольшие значения среди представленных стран у Германии, Чехии и Франции, наименьшие значения - у России, Австралии, Казахстана. В Беларуси показатель составил приблизительно 0,46 п., что является значением ниже среднего среди значений рассмотренных стран (таблица 8).

Наибольшие значения доли экспорта промышленной продукции в общем объеме экспорта среди представленных стран наблюдаются у Китая, Чехии и Германии, наименьшие значения - у России, Казахстана, Австралии. В Беларуси показатель составил около 0,7 п., что является значением выше среднего среди значений рассмотренных стран.

Заключение. Подводя итог, стоит отметить, что Беларусь выдерживает сравнение с другими странами по экономическим показателям, в том числе и со странами-лидерами. Обрабатывающая промышленность представлена многими подсекциями, по некоторым подсекциям Беларусь имеет конкурентное преимущество на мировой арене.

Наибольшую долю в структуре обрабатывающей промышленности в Республике Беларусь занимает подсекция «Еда и на-

\section{Показатели технологичности в 2010 и 2017 гг. [3]}

Таблица 6

\begin{tabular}{|l|c|c|c|c|}
\hline \multirow{2}{*}{ Страна } & \multicolumn{4}{|c|}{ Показатели технологичности } \\
\cline { 2 - 5 } & $\begin{array}{c}\text { Доля ДС средне- } \\
\text { и высокотехн. } \\
\text { пр-ва в общей } \\
\text { ДС пр-ва }\end{array}$ & $\begin{array}{c}\text { Доля экспорта } \\
\text { средне- и высокотехн. } \\
\text { товаров в общем } \\
\text { объеме экспорта }\end{array}$ & $\begin{array}{c}\text { Доля ДС средне- } \\
\text { и высокотехн. } \\
\text { пр-ва в общей } \\
\text { ДС пр-ва }\end{array}$ & $\begin{array}{c}\text { Доля экспорта } \\
\text { среде- и высокотехн. } \\
\text { товаров в общем } \\
\text { объеме экспорта }\end{array}$ \\
\hline Австралия & 0,28 & 0,2 & 0,28 & 0,19 \\
\hline Беларусь & 0,4 & 0,39 & 0,39 & 0,4 \\
\hline Германия & 0,6 & 0,72 & 0,62 & 0,74 \\
\hline Испания & 0,38 & 0,57 & 0,4 & 0,57 \\
\hline Италия & 0,43 & 0,54 & 0,43 & 0,55 \\
\hline Казахстан & 0,13 & 0,37 & 0,13 & 0,36 \\
\hline Китай & 0,41 & 0,61 & 0,41 & 0,6 \\
\hline Латвия & 0,23 & 0,35 & 0,21 & 0,43 \\
\hline Литва & 0,3 & 0,38 & 0,25 & 0,43 \\
\hline Польша & 0,39 & 0,58 & 0,34 & 0,29 \\
\hline Россия & 0,25 & 0,24 & 0,3 & 0,64 \\
\hline США & 0,48 & 0,65 & 0,47 & 0,66 \\
\hline Франция & 0,48 & 0,66 & 0,51 & 0,7 \\
\hline Чехия & 0,45 & 0,68 & 0,52 & 0,5 \\
\hline Эстония & 0,28 & 0,42 & 0,27 & \\
\hline
\end{tabular}


питки». Подобная ситуация наблюдается и в других странах. Однако, в некоторых развитых странах в структуре обрабатывающей промышленности превалируют подсекции, выпускающие продукцию с более высокой ВДС, такие как «Автомобили, прицепы и полуприцепы», «Машины и оборудование», «Химикаты и химические продукты», и являющиеся также ориентированными на экспорт.

Показатели технологичности, экспорта, экспорта в промышленности Беларуси демонстрируют средние значения среди рассмотренных стран. Наименьшие значения наблюдались в индексах таких стран, как Россия, Казахстан, Латвия, Австралия, наибольшие значения — в индексах Германии, Чехии и Франции.

Так как основой устойчивого развития и обеспечения социально-экономической безопасности является экономика, базирую- щаяся на инновациях и эффективном использовании национальных ресурсов, развитие высокотехнологичных производств, индустриализация и содействие инновациям при рациональном использовании природных ресурсов - это движущие силы экономического роста и устойчивого развития Беларуси [1]. Перестройка национальной экономики должна быть основана на опережающем развитии науки и высокотехнологичных производств, продвижении инновационных технологий и их продуктов в традиционный сектор экономики.

Данная статья подготовлена в рамках комплексного исследования, посвященного совершенствованию структуры экономики регионов областного и районного уровней Республики Беларусь. Далее планируется подготовить конкретные рекомендации по совершенствованию территориальной, отраслевой, секторальной, технологичес-

Таблица 7

Показатели экспорта в 2010 и 2017 гг. (составлено автором на основании стат. базы данных ООН)

\begin{tabular}{|l|c|c|c|c|}
\hline \multirow{2}{*}{ Страна } & \multicolumn{4}{|c|}{ Показатели экспорта } \\
\cline { 2 - 5 } & $\begin{array}{c}\text { Индекс экспорта } \\
\text { производства на } \\
\text { душу населения }\end{array}$ & $\begin{array}{c}\text { Доля экспорта } \\
\text { промышленной } \\
\text { объеме экспорта }\end{array}$ & $\begin{array}{c}\text { Индекс экспорта } \\
\text { производства на } \\
\text { душу населения }\end{array}$ & $\begin{array}{c}\text { Доля экспорта } \\
\text { промышодукций } \\
\text { объеме экспорта }\end{array}$ \\
\hline Австралия & 0,14 & 0,48 & 0,12 & 0,45 \\
\hline Беларусь & 0,07 & 0,91 & 0,08 & 0,88 \\
\hline Германия & 0,42 & 0,89 & 0,48 & 0,92 \\
\hline Испания & 0,14 & 0,86 & 0,17 & 0,84 \\
\hline Италия & 0,21 & 0,94 & 0,23 & 0,95 \\
\hline Казахстан & 0,02 & 0,23 & 0,02 & 0,28 \\
\hline Китай & 0,03 & 0,99 & 0,05 & 0,99 \\
\hline Латвия & 0,1 & 0,83 & 0,17 & 0,84 \\
\hline Литва & 0,18 & 0,88 & 0,27 & 0,91 \\
\hline Польша & 0,11 & 0,9 & 0,15 & 0,91 \\
\hline Россия & 0,03 & 0,36 & 0,03 & 0,46 \\
\hline США & 0,09 & 0,79 & 0,09 & 0,75 \\
\hline Франция & 0,22 & 0,91 & 0,22 & 0,91 \\
\hline Чехия & 0,35 & 0,93 & 0,49 & 0,97 \\
\hline Эстония & 0,25 & 0,88 & 0,3 & 0,87 \\
\hline
\end{tabular}


Показатели экспорта в промышленности в 2010 и 2017 гг. (составлено автором на основании стат. базы данных ООН)

\begin{tabular}{|l|c|c|c|c|}
\hline \multirow{2}{*}{ Страна } & \multicolumn{3}{|c|}{ Показатели экспорта в промышленности } \\
\cline { 2 - 5 } & $\begin{array}{c}\text { Доля средне- и } \\
\text { высокотехн. деят-ти } \\
\text { в индексе экспорта } \\
\text { обрабат. пром-ти }\end{array}$ & $\begin{array}{c}\text { Индекс качества } \\
\text { промышленного } \\
\text { экспорта }\end{array}$ & $\begin{array}{c}\text { Доля средне- и } \\
\text { высокотехн. деят-ти } \\
\text { в индексе экспорта } \\
\text { обрабат. пром-ти }\end{array}$ & $\begin{array}{c}\text { Индекс качества } \\
\text { промышленного } \\
\text { экспорта }\end{array}$ \\
\hline Австралия & 0,24 & 0,36 & 0,2 & 0,32 \\
\hline Беларусь & 0,47 & 0,69 & 0,41 & 0,65 \\
\hline Германия & 0,87 & 0,88 & 0,77 & 0,85 \\
\hline Испания & 0,69 & 0,77 & 0,59 & 0,71 \\
\hline Италия & 0,65 & 0,79 & 0,57 & 0,76 \\
\hline Казахстан & 0,45 & 0,34 & 0,38 & 0,33 \\
\hline Китай & 0,73 & 0,86 & 0,62 & 0,81 \\
\hline Латвия & 0,42 & 0,62 & 0,44 & 0,64 \\
\hline Литва & 0,45 & 0,67 & 0,45 & 0,68 \\
\hline Польша & 0,7 & 0,8 & 0,58 & 0,74 \\
\hline Россия & 0,29 & 0,32 & 0,3 & 0,38 \\
\hline США & 0,78 & 0,78 & 0,66 & 0,71 \\
\hline Франция & 0,79 & 0,85 & 0,69 & 0,8 \\
\hline Чехия & 0,81 & 0,87 & 0,73 & 0,85 \\
\hline Эстония & 0,51 & 0,69 & 0,52 & 0,7 \\
\hline
\end{tabular}

кой, региональной, инвестиционной, инновационной структур экономики регионов Республики Беларусь, структуры форм собственности, основываясь на проведенном анализе структур, а также международном опыте совершенствования структур экономики региона.

\section{Литература}

1. Аналитический отчет о реализации в 2016-2017 гг. Национальной стратегии устойчивого социально-экономического развития Республики Беларусь на период до 2030 года. Минск: Медисонт, 2019. - 234 с.

2. Камына М.В. Методологические основы исследования и совершенствования структуры национальной и региональной экономики / М.В. Камына // Весник ГрГУ. Серия 5. - 2015. - №1 (188). - С. 50-58.
3. Статистическая база данных Организации промышленного развития $\mathrm{OOH}$ (UNIDO) [Электронный ресурс]. - Режим доступа: https://stat.unido.org (Дата обращения: 10.11.2019).

4. Развадовская Ю.В. Анализ отечественного и зарубежного опыта управления структурными преобразованиями экономики промышленного сектора / Ю.В. Развадовская // Электронный научный журнал «Инженерный вестник Дона». — 2011. №4.

5. Угарина Т.А. Структурные преобразования в экономике: опыт зарубежных стран / Т.А. Угарина // Эконом. Бюллетень НИЭИ Мин-ва экономики Респ. Беларусь. - 2013. №1. - С. 40-46.

6. Фатеев В.С. Региональная политика: теория и практика / В. С. Фатеев. - Мн.: ЕГУ, 2004. - $480 \mathrm{c}$. 


\section{References}

1. Analiticheskij otchet o realizacii v 20162017 gg. Nacional'noj strategii ustojchivogo social'no-jekonomicheskogo razvitija Respubliki Belarus' na period do 2030 goda [Analytical report on implementation in 2016-2017 National strategy for sustainable socio-economic development of the Republic of Belarus for the period up to 2030]. - Minsk: Medisont, 2019. - 234 p.

2. Kamyna M. V. Metodologicheskie osnovy issledovanija i sovershenstvovanija struktury nacional'noj i regional'noj jekonomiki [Methodological foundations of research and improvement of the structure of the national and regional economy] / M. V. Kamyna // Vesnik GrGU. Serija 5. — 2015. — №1 (188). — Pp. 50-58.

3. Statisticheskaja baza dannyh Organizacii promyshlennogo razvitija OON (UNIDO) [Statistical database of the United Nations industrial development Organization (UNIDO)] [Jele- ktronnyj resurs]. — URL: https://stat.unido.org (Date accessed: 10.11.2019).

4. Razvadovskaja Ju. V. Analiz otechestvennogo i zarubezhnogo opyta upravlenija strukturnymi preobrazovanijami jekonomiki promyshlennogo sektora [Analysis of domestic and foreign experience in managing structural transformations of the industrial sector economy] / Ju. V. Razvadovskaja // Jelektronnyj nauchnyj zhurnal «Inzhenernyj vestnik Dona» [Electronic scientific journal «Engineering Bulletin of Don»]. — 2011. — №4.

5. Ugarina T.A. Strukturnye preobrazovanija v jekonomike: opyt zarubezhnyh stran [Structural changes in the economy: foreign experience] / T. A. Ugarina // Jekonom. Bjulleten'NIJeI Min-va jekonomiki Resp. Belarus'. — 2013. №1. - Pp. 40-46.

6. Fateev V.S. Regional'naja politika: teorija i praktika [Regional policy: theory and practice]/ V. S. Fateev. - Minsk: EGU, 2004. — 480 p.

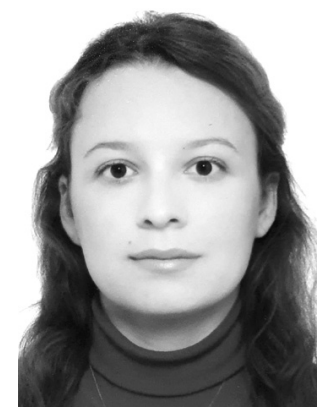

Камына Марина Владимировна - аспирант факультета экономики и управления УО «Гродненский государственный университет имени Янки Купалы», магистр экономических наук.

Kamyna Marina Vladimirovna - Postgraduate Student of the faculty of Economics and Management Chair of EE «Grodno State University named Yanka Kupala», Master of Economic Sciences.

230025, Беларусь, г. Гродно, ул. К. Маркса, 13, кв. 3

13 K. Marx st., app. 3, 230025, Grodno, Belarus

E-mail: Marina-bldrv@yandex.ru 